Archives of Agriculture and Environmental Science

\title{
Nitrogen uptake and economics of black rice (Oryza sativa L. indica) under different crop geometries and nitrogen management practices
}

\author{
Suraj Singh Karkee ${ }^{1^{*}}$ (D), Shrawan Kumar Sah ${ }^{1}$, Santosh Marhatta ${ }^{1}$, Suman Dhakal ${ }^{1}$, Manoj \\ Kandel $^{2}$ and Jiban Shrestha ${ }^{3}$ \\ ${ }^{1}$ Agriculture and Forestry University, Rampur Chitwan, NEPAL \\ ${ }^{2}$ Nepal Agricultural Research Council, Hill Crops Research Program (HCRP), Baiteshwor-4, Dolakha, NEPAL \\ ${ }^{3}$ Nepal Agricultural Research Council, Agriculture Botany Division (ABD), Khumaltar, Lalitpur, NEPAL \\ *Corresponding author's E-mail: surazkarkee23@gmail.com
}

\section{ARTICLE HISTORY}

Received: 09 April 2019

Revised received: 07 May 2019

Accepted: 21 May 2019

\section{Keywords}

Black rice

Crop geometrics

Economics

Nitrogen uptake

Nitrogen management practices

\section{ABSTRACT}

Black rice has more antioxidants than any other rice variety. It is considered to have multiple benefits in human health due to the presence of different antioxidants. A field experiment was conducted during rainy season of 2015-2016 to assess the nitrogen uptake, use efficiency and economics of black rice production under different crop geometry and nitrogen $(\mathrm{N})$ management practices in Rampur, Chitwan, Nepal. The experiment was laid out in strip plot design with three replications. The experiment consisted of treatment combination of three crop geometry $(20 \mathrm{~cm} \times 20 \mathrm{~cm}, 20 \mathrm{~cm} \times 15 \mathrm{~cm}$ and $15 \mathrm{~cm} \times 15 \mathrm{~cm})$ in vertical plots and three nitrogen management practices ( $\mathrm{N}$ level: $30 \mathrm{~kg} \mathrm{~N} \mathrm{ha}^{-1}, 60 \mathrm{~kg} \mathrm{~N}^{-1}$, and LCC based N-management) in horizontal plots. The results showed that the highest $\mathrm{N}$ uptake was recorded from closer spacing $(15 \mathrm{~cm} \times 15 \mathrm{~cm}$ ) with LCC based $\mathrm{N}$ management. The net return and B: C ratios were higher at a closer spacing of $15 \mathrm{~cm} \times 15 \mathrm{~cm}$ with LCC based $\mathrm{N}$ management and closer spacing of $15 \mathrm{~cm} \times 15 \mathrm{~cm}$ with $\mathrm{N}$ application of $60 \mathrm{~kg} \mathrm{ha}^{-1}$. The overall analysis revealed that LCC based $\mathrm{N}$ management under closer crop geometry $(15 \mathrm{~cm} \times 15 \mathrm{~cm})$ was the best management practices because of high nitrogen uptake and highest monetary return with $\mathrm{B}: \mathrm{C}$ ratio of 5.76 .

(C)2019 Agriculture and Environmental Science Academy

Citation of this article: Karkee, S.S., Sah, S.K., Marhatta, S., Dhakal, S., Kandel, M. and Shrestha, J. (2019). Nitrogen uptake and economics of black rice (Oryza sativa L. indica) under different crop geometries and nitrogen management practices. Archives of Agriculture and Environmental Science, 4(2): 171-176, https://dx.doi.org/10.26832/24566632.2019.040207

\section{INTRODUCTION}

Black or pigment rice is rice of high demand. The popularity of this rice is due to its health benefit, high demand among urban societies and high market value. The antioxidant property of rice is due to anthocyanin content and it is also rich in fiber, several minerals like Fe, Mn, Cu, etc. (Kushwaha, 2016). The accumulation of anthocyanin in different layer of the pericarp and aleuronic region makes rice black or deep purple in color (Chaudhary, 2003). Nitrogen is one of the most important essential nutrients for growth of plant as it is important component of RNA, DNA, amino acids, nucleic acids, nucleotides, chlorophyll, enzymes, and hormones. The chlorophyll present in the leaves determines the ability of crop to utilize solar radiation, which depends upon uptake of nitrogen from soil
(Peng et al., 1955). Crop geometry is an arrangement of the plant in different rows and column in an area. It is an important factor for optimizing spacing between plants for efficient utilization of the natural resources like light, water, nutrient and space (Haque et al., 2012). Crop geometry in plant varied according to genetic characteristics of the plant (size of the plant, elasticity of the plant, foraging area or soil cover dry matter partitioning and crop and variety), time of sowing, environmental factors, and fertilizer application.

There is limited information on $\mathrm{N}$ uptake and use efficiency by black rice grown under different $\mathrm{N}$ management practices. Mineral uptake is the process in which minerals enter the cellular mineral through plant roots, typically following the same pathway of water. Plants absorb minerals in ionic form: nitrogen enters as nitrate $\left(\mathrm{NH}_{4}{ }^{+}\right)$or ammonium ion $\left(\mathrm{NO}_{3}{ }^{-}\right)$. 
A large portion of applied nitrogen losses from flooded rice field which contribute to the low $\mathrm{N}$ use efficiency of rice as compared to another crop. Rakshit et al. (2014) reported that an average $N$ recovery efficiency for fields managed by farmers ranging from 20 to $30 \%$ under rainfed conditions and $30-40 \%$ under irrigated conditions. Major driving processes responsible for these heavy losses from rice field are Volatilization, nitrification, denitrification, and leaching (Aulakh and Singh, 1996). Nitrogen Use Efficiency (NUE) is a term used to indicate the ratio between the amount of fertilizer $\mathrm{N}$ removed from the field by the crop and the amount of fertilizer $\mathrm{N}$ applied. Khadka (2016) performed experiment in response of Black rice to different dose of nitrogen and found that black rice var.G60 is very low response to nitrogen. A field experiment was conducted with objectives to known the nitrogen uptake, use efficiencies and economics of black since rice is not only a source of food, it is also a major employer and source of income for people.

\section{MATERIALS AND METHODS}

The experiment was conducted at the Agronomy Farm of Agriculture and Forestry University (AFU), Rampur, Chitwan, Nepal during July to December 2015-2016. The soil of the experimental field was silty loam in texture and acidic in reaction ( $\mathrm{pH} 5.71$ ) with low organic matter content (2.47 \%). The total nitrogen, available phosphorus and exchangeable potassium were $0.12 \%, 35.22 \mathrm{~kg} \mathrm{ha}^{-1}, 57.77 \mathrm{~kg} \mathrm{ha}^{-1}$ soil. The total rainfall during the crop season was $1707.6 \mathrm{~mm}$ and the relative humidity ranged from $75.0 \%$ in June and $89.7 \%$ in October. The mean Maximum temperature during the experimental period ranged from $30.84^{\circ} \mathrm{C}$ to $35.18^{\circ} \mathrm{C}$.

The experiment was laid out in strip plot design with two factors with three replications. The horizontal factor consisted of three crop geometry $(20 \mathrm{~cm} \times 20 \mathrm{~cm}, 20 \mathrm{~cm} \times 15 \mathrm{~cm}$, and $15 \mathrm{~cm} \times 15$ $\mathrm{cm}$ ) and vertical factor consisted of three nitrogen management practices (30 kg N ha ${ }^{-1}, 60 \mathrm{~kg} \mathrm{~N} \mathrm{ha}^{-1}$, and LCC based $\mathrm{N}$ application). The plot size was $3 \mathrm{~m} \times 4.2 \mathrm{~m}$. Black rice (var. G 60) seedlings were raised in well prepared dry seed bed. Rice seed was sown on June 8,2016 with the seed rate of $50 \mathrm{~kg} \mathrm{ha}^{-1}$. The nursery bed was fertilized through using Urea and SSP with 2.25 $\mathrm{g} \mathrm{m}^{-2}$ and $50 \mathrm{~g} \mathrm{~m}^{-2}$, respectively and mulched using wheat straw. Frequent irrigation through hand watering jar was given to recover the seedling from drought. Twenty six old seedlings were uprooted carefully from the nursery and transplanted (2-3 seedlings/hill) on the well puddled experimental plots on with three crop geometry as treatments. Full dose of phosphorous, potash and $25 \mathrm{~kg} \mathrm{ha}^{-1} \mathrm{ZnSO}_{4}$ were applied as basal dose. Basal doses of nitrogen were applied in $30 \mathrm{~kg} \mathrm{ha}^{-1}$ and $60 \mathrm{~kg} \mathrm{ha}^{-1}$ nitrogen treatment @ $30 \mathrm{~kg} \mathrm{ha}^{-1}$. Remaining nitrogen dose of treatment $60 \mathrm{~kg}$ $\mathrm{ha}^{-1}$ was applied during active tillering stage after first hand weeding. In LCC no nitrogen was applied as basal dose. First reading of LCC was done at 15 DAT the value of $L C C$ was found below critical ( $<4$ ) and $30 \mathrm{~kg} \mathrm{ha}^{-1}$ nitrogen was applied at a time. Similarly $2^{\text {nd }}$ split of nitrogen using LCC was applied at 36 DAT which was $3^{\text {rd }}$ reading of LCC. The crop of individual plots was separately harvested at full maturity. Data on nitrogen content of grain and straw was obtained by adopting Kjeldahl method and benefit cost ratio was calculated after taking data of biological yield. The price rate of rice grain was NRs. 250/ kg and rice straw was NRs. $3.25 / \mathrm{kg}$. Total N uptake was determined by the formula adopted by Sikdar et al. (2008). Data analysis was done with Microsoft Excel ver. 2016 and R-program. Data were subjected to analysis of variance (ANOVA) tests. When significant differences were found, means were separated and assessed using Duncan's Multiple Range Test (DMRT).

\section{RESULTS AND DISCUSSION}

\section{Effect of crop geometry and nitrogen management}

\section{Nitrogen uptake and use efficiency}

Grain nitrogen uptake, Straw nitrogen uptake and total nitrogen uptake was found non-significant under different crop geometry and nitrogen management practices (Table 1). Grain nitrogen uptake and total nitrogen uptake was significantly influenced where as straw nitrogen uptake was found non-significant under different nitrogen management practices (Table 1). Higher total nitrogen uptake in $60 \mathrm{~kg} \mathrm{ha}^{-1}$ and LCC might be due to higher uptake of nitrogen with higher availability. Similarly, total nitrogen uptake in LCC based nitrogen management is relatively higher than nitrogen applied at the rate of $60 \mathrm{~kg} \mathrm{ha}^{-1}$ this might be due to fewer loss results more uptake of applied nitrogen. Similar result was found by (Bhat et al., 2017) and (Kumar et al., 2010)

Partial factor productivity of applied Nitrogen (PFP-N), Nitrogen Efficiency Ratio (NER), and Internal Efficiency (IE) were found non-significant in case of crop geometry (Table 2). Similarly Nitrogen Efficiency Ratio (NER), and Internal Efficiency (IE) was found non-significant in case of nitrogen management practices but Partial factor productivity of applied nitrogen (PFP $-N)$ was significantly influenced and found significantly higher in $30 \mathrm{~kg} \mathrm{ha}^{-1}$ than others (Table 2). Partial factor productivity is found relatively higher in LCC based $\mathrm{N}$ management then same amount $\left(60 \mathrm{~kg} \mathrm{ha}^{-1}\right)$ applied adopting splitting this might be due to higher uptake of nutrient in LCC based $\mathrm{N}$ management. Decline in partial factor productivity at higher level of $\mathrm{N}$ may be due to decline in indigenous soil $\mathrm{N}$ supply and low response of black rice to applied N. Khadka (2016) found that black rice var.G60 is very low response to nitrogen. Major decline in partial factor productivity for $\mathrm{N}$ might be due to nutrient imbalance, decline in indigenous soil $\mathrm{N}$ supply, subsoil compaction, reduction of root volume and increased disease and pest incidence (Karim and Ramasamy, 2000).

\section{Economics}

The cost of cultivation greatly differed among the crop geometry and nitrogen management practice (Table 3). On an average, the lowest cost of cultivation was found in wider spacing $(20 \mathrm{~cm}$ $\times 20 \mathrm{~cm})$ by $10.78 \%$ and $14.38 \%$ than the spacing $(15 \mathrm{~cm} \times 15$ $\mathrm{cm})$ and spacing $(20 \mathrm{~cm} \times 20 \mathrm{~cm})$ respectively. Cultivation cost was increased as geometry between crop and row decreases, 
Table 1. Grain nitrogen uptake, straw nitrogen uptake and total nitrogen uptake as influenced by crop geometry and nitrogen management at Rampur, Chitwan in 2015-16.

\begin{tabular}{|c|c|c|c|}
\hline \multirow[b]{2}{*}{ Treatment } & \multicolumn{3}{|c|}{ Nitrogen uptake $\left(\mathrm{kg} \mathrm{ha}^{-1}\right)$} \\
\hline & $\begin{array}{c}\text { Straw nitrogen } \\
\text { uptake (SNU) kg ha-1 }\end{array}$ & $\begin{array}{l}\text { Grain nitrogen } \\
\text { uptake (GNU) kg ha }\end{array}$ & $\begin{array}{c}\text { Total nitrogen } \\
\text { uptake (TNU) kg ha }{ }^{-1}\end{array}$ \\
\hline \multicolumn{4}{|c|}{ Horizontal factor: Crop geometry } \\
\hline $20 \mathrm{~cm} \times 20 \mathrm{~cm}$ & 25.9 & 12.22 & 38.2 \\
\hline $20 \mathrm{~cm} \times 15 \mathrm{~cm}$ & 33.1 & 14.46 & 47.6 \\
\hline $15 \mathrm{~cm} \times 15 \mathrm{~cm}$ & 35.3 & 16.58 & 51.9 \\
\hline LSD (0.05) & NS & Ns & NS \\
\hline $\operatorname{SEm}( \pm)$ & 2.18 & 1.27 & 3.11 \\
\hline$C V(\%)$ & 12.0 & 15.3 & 11.7 \\
\hline \multicolumn{4}{|c|}{ Vertical factor: Nitrogen management } \\
\hline $30 \mathrm{~kg} \mathrm{ha}^{-1}$ & 28.3 & $11.86^{b}$ & $40.1^{b}$ \\
\hline $60 \mathrm{~kg} \mathrm{ha}^{-1}$ & 31.6 & $15.21^{\mathrm{a}}$ & $46.8^{\mathrm{ab}}$ \\
\hline $\operatorname{LCC}\left(60 \mathrm{~kg} \mathrm{ha}^{-1}\right)$ & 34.5 & $16.20^{\mathrm{a}}$ & $50.7^{\mathrm{a}}$ \\
\hline $\operatorname{LSD}(0.05)$ & NS & 2.35 & 6.86 \\
\hline $\operatorname{Sem}( \pm)$ & 1.30 & 0.60 & 1.75 \\
\hline$C V(\%)$ & 7.1 & 7.2 & 6.6 \\
\hline Grand mean & 31.5 & 14.42 & 45.9 \\
\hline
\end{tabular}

Treatment means in columns followed by common letters are not significantly different from each other based on DMRT at $5 \%$ level of significance.

Table 2. Nitrogen use efficiency of black rice as influenced by crop geometry and nitrogen management at Rampur, Chitwan in 201516.

\begin{tabular}{|c|c|c|c|}
\hline \multirow[b]{2}{*}{ Treatment } & \multicolumn{3}{|c|}{ Nitrogen use efficiency } \\
\hline & $\begin{array}{l}\text { Partial factor productivity of } \\
\text { applied nitrogen (PFP-N) }\end{array}$ & $\begin{array}{l}\text { Nitrogen efficiency } \\
\text { ratio (NER) }\end{array}$ & $\begin{array}{l}\text { Internal efficiency } \\
\text { (IE) }\end{array}$ \\
\hline \multicolumn{4}{|c|}{ Horizontal factor: crop geometry } \\
\hline $20 \mathrm{~cm} \times 20 \mathrm{~cm}$ & 18.34 & 94.6 & 21.96 \\
\hline $20 \mathrm{~cm} \times 15 \mathrm{~cm}$ & 19.98 & 85.0 & 19.31 \\
\hline $15 \mathrm{~cm} \times 15 \mathrm{~cm}$ & 24.26 & 89.1 & 22.71 \\
\hline $\operatorname{LSD}(0.05)$ & NS & NS & NS \\
\hline $\operatorname{SEm}( \pm)$ & 1.22 & 5.37 & 0.82 \\
\hline $\mathrm{CV}(\%)$ & 10.1 & 10.4 & 6.7 \\
\hline \multicolumn{4}{|c|}{ Vertical factor: Nitrogen management } \\
\hline $30 \mathrm{~kg} \mathrm{ha}^{-1}$ & $27.75^{a}$ & 93.7 & 21.41 \\
\hline $60 \mathrm{~kg} \mathrm{ha}^{-1}$ & $16.38^{b}$ & 86.6 & 20.71 \\
\hline $\operatorname{LCC}\left(60 \mathrm{~kg} \mathrm{ha}^{-1}\right)$ & $18.44^{b}$ & 88.5 & 21.87 \\
\hline $\operatorname{LSD}(0.05)$ & 3.20 & NS & NS \\
\hline $\operatorname{SEm}( \pm)$ & 0.82 & 4.69 & 0.72 \\
\hline $\mathrm{CV}(\%)$ & 6.8 & 9.1 & 5.8 \\
\hline Grand mean & 20.86 & 89.6 & 21.33 \\
\hline
\end{tabular}

Treatment means in columns followed by common letters are not significantly different from each other based on DMRT at $5 \%$ level of significance.

this may be due to more seed requirement, more labor for transplanting and higher requirement of other input. Cultivation cost increases as nitrogen dose increases. When LCC is adopted the cultivation cost was increased this might be due to increased cost for the additional amount of nitrogen and labor for LCC adoption. Gross return and Net return was significantly higher in narrow crop geometry $15 \mathrm{~cm} \times 15 \mathrm{~cm}$ than other crop geometry of $20 \mathrm{~cm} \times 15 \mathrm{~cm}$ and $20 \mathrm{~cm} \times 20 \mathrm{~cm}$ (Table 3). This might be due to higher biological yield from narrow geometry. Mondal et al. (2013) also found that high density paid highest gross and net return. B: C ratio was non- significant among treatments but it goes on increasing as space between crops and rows goes on decreasing (Table 3). This may be due to the higher requirement of inputs like labor, seed results in higher input cost in closer geometry. But relatively higher B: C ratio was obtained from narrow crop geometry. Jena et al. (2010) found that highest monetary return and highest $\mathrm{B}: \mathrm{C}$ ratio was from plant spacing $15 \mathrm{~cm} \times 15 \mathrm{~cm}$. Gross return and Net return was significantly higher in LCC based nitrogen management followed by $60 \mathrm{~kg}$ $\mathrm{Nha}^{-1}$. Similarly the $\mathrm{B}$ : C ratio was significantly different among treatments, it goes on increasing as nitrogen rate goes on increasing and found significantly highest in LCC based nitrogen management than others (Table 3). Satpute et al. (2014) and Maiti et al. (2004) also favors the use of LCC for nitrogen management in rice as it increases return by decreasing nitrogen use as well as increasing yield of rice as compared to $\mathrm{N}$ broadcasting. 
Interaction effect of crop geometry and nitrogen management The interaction effect between crop geometry and Nitrogen management Practices was significant in Grain Nitrogen Uptake. Significantly higher Grain Nitrogen Uptake was obtained from treatment combination closer geometry $(15 \mathrm{~cm} \times$ $15 \mathrm{~cm}$ ) with LCC based $\mathrm{N}$ management (21.21 $\mathrm{kg} \mathrm{ha}^{-1}$ ) (Table 4). Field applied $\mathrm{N}$ adopting LCC and closer spacing had higher biological yield. Higher $\mathrm{N}$ uptake was obtained when better synchronization of $\mathrm{N}$ supply with crop $\mathrm{N}$ demand (Dhyani et al., 2017). Similarly, closer crop geometry consists of high density planting resulting higher biomass production and record higher nitrogen uptake (Dhyani et al., 2017).

B: C ratio, Net return and Gross return were significantly influenced by Interaction effect between crop geometry and Nitrogen management Practices (Tables 5-7). Significantly higher Gross return (488.9 thousand ha ${ }^{-1}$ ), Net return (404.0 thousand $\mathrm{ha}^{-1}$ ) and $\mathrm{B}: \mathrm{C}$ (5.76) ratio was obtained from interaction of Closer geometry $(15 \mathrm{~cm} \times 15 \mathrm{~cm})$ with LCC based $\mathrm{N}$ management. It might be due higher biological yield results higher net return.

Table 3. Cost of cultivation, gross return, net returns, and B: C ratio of black rice as influenced by crop geometry and nitrogen management at Rampur, Chitwan in 2015-16.

\begin{tabular}{|c|c|c|c|c|}
\hline Treatments & $\begin{array}{l}\text { Total Production cost } \\
\left(\text { NRs.ha }^{-1}\right)(000)\end{array}$ & $\begin{array}{l}\text { Gross returns } \\
\left(\text { NRs.ha }^{-1}\right)(000)\end{array}$ & $\begin{array}{l}\text { Net return } \\
\left(\text { NRs.ha }^{-1}\right)(000)\end{array}$ & B:C ratio \\
\hline \multicolumn{5}{|c|}{ Horizontal factor: Crop geometry } \\
\hline $20 \mathrm{~cm} \times 20 \mathrm{~cm}$ & 74.46 & $246.02^{b}$ & $171.56^{\mathrm{b}}$ & 3.30 \\
\hline $20 \mathrm{~cm} \times 15 \mathrm{~cm}$ & 79.46 & $270.25^{b}$ & $190.79^{b}$ & 3.40 \\
\hline $15 \mathrm{~cm} \times 15 \mathrm{~cm}$ & 83.46 & $344.01^{\mathrm{a}}$ & $260.54^{a}$ & 4.11 \\
\hline LSD (0.05) & & 69.07 & 57.769 & NS \\
\hline $\operatorname{SEm}( \pm)$ & & 14.71 & 14.71 & 0.18 \\
\hline $\mathrm{C.V}(\%)$ & & 8.9 & 12.3 & 8.8 \\
\hline \multicolumn{5}{|c|}{ Vertical factor: Nitrogen management } \\
\hline $30 \mathrm{~kg} \mathrm{ha}^{-1}$ & 77.40 & $245.68^{c}$ & $168.29^{c}$ & $3.17^{c}$ \\
\hline $60 \mathrm{~kg} \mathrm{ha}^{-1}$ & 79.40 & $289.28^{b}$ & $209.88^{b}$ & $3.61^{\mathrm{b}}$ \\
\hline LCC (60 kg ha $\left.{ }^{-1}\right)$ & 80.60 & $325.32^{\mathrm{a}}$ & $244.72^{\mathrm{a}}$ & $4.02^{\mathrm{a}}$ \\
\hline $\operatorname{LSD}(0.05)$ & & 37.57 & 31.47 & 0.386 \\
\hline $\operatorname{SEm}( \pm)$ & & 8.016 & 8.02 & 0.098 \\
\hline $\mathrm{CV}(\%)$ & & 4.8 & 6.7 & 4.7 \\
\hline Grand Mean & 79.13 & 286.76 & 207.63 & 3.60 \\
\hline
\end{tabular}

Treatment means in columns followed by common letters are not significantly different from each other based on DMRT at $5 \%$ level of significance

Table 4. GNU of black rice as influenced by the interaction between crop geometry and N management at Rampur, Chitwan in 201516.

\begin{tabular}{llll}
\hline \multirow{2}{*}{ Nitrogen management practices } & \multicolumn{2}{c}{ GNU $\left(\mathrm{kg} \mathrm{ha}^{-1}\right)$} \\
\cline { 2 - 3 } & \multicolumn{2}{c}{ Crop geometry } \\
\cline { 2 - 3 } & $20 \mathrm{~cm} \times 20 \mathrm{~cm}$ & $20 \mathrm{~cm} \times 15 \mathrm{~cm}$ & $15 \mathrm{~cm} \times 15 \mathrm{~cm}$ \\
\hline $30 \mathrm{~kg} \mathrm{ha}^{-1}$ & $11.98^{\mathrm{d}}$ & $12.68^{\mathrm{cd}}$ & $10.06^{\mathrm{d}}$ \\
$60 \mathrm{~kg} \mathrm{ha}^{-1}$ & $9.99^{\mathrm{d}}$ & $17.17^{\mathrm{abc}}$ & $18.48^{\mathrm{ab}}$ \\
$\mathrm{LCC}\left(60 \mathrm{~kg} \mathrm{ha}^{-1}\right)$ & $14.69^{\mathrm{bcd}}$ & $13.53^{\mathrm{cd}}$ & $21.21^{\mathrm{a}}$ \\
\hline
\end{tabular}

Treatment means in columns followed by common letters are not significantly different from each other based on DMRT at $5 \%$ level of significance.

Table 5. Net return of black rice as influenced by the interaction between crop geometry and N management at Rampur, Chitwan in 2015-16.

\begin{tabular}{llll}
\hline \multirow{2}{*}{ Nitrogen management practices } & \multicolumn{2}{c}{ Crop geometry } \\
\cline { 2 - 3 } & \multicolumn{2}{c}{$20 \mathrm{~cm} \times 20 \mathrm{~cm}$} & $15 \mathrm{~cm} \times 15 \mathrm{~cm}$ \\
\cline { 2 - 4 } $30 \mathrm{~kg} \mathrm{ha}^{-1}$ & $206.7^{\mathrm{cd}}$ & $234.5^{\mathrm{cd}}$ & $217.7^{\mathrm{cd}}$ \\
$60 \mathrm{~kg} \mathrm{ha}^{-1}$ & $166.1^{\mathrm{d}}$ & $271.4^{\mathrm{bc}}$ & $359.7^{\mathrm{ab}}$ \\
LCC $\left(60 \mathrm{~kg} \mathrm{ha}^{-1}\right)$ & $284.2^{\mathrm{bc}}$ & $222.4^{\mathrm{cd}}$ & $404.0^{\mathrm{a}}$ \\
\hline
\end{tabular}

Treatment means in columns followed by common letters are not significantly different from each other based on DMRT at $5 \%$ level of significance. 
Table 6. Gross return of black rice as influenced by the interaction between crop geometry and N management at Rampur, Chitwan in 2015-16.

Gross return (NRs. thousand $\mathrm{ha}^{-1}$ )

\begin{tabular}{llll} 
Nitrogen management practices & \multicolumn{2}{c}{ Crop geometry } \\
\cline { 2 - 4 } & $20 \mathrm{~cm} \times 20 \mathrm{~cm}$ & $\mathbf{2 0 c m} \times 15 \mathrm{~cm}$ & $15 \mathrm{~cm} \times 15 \mathrm{~cm}$ \\
\hline $30 \mathrm{~kg} \mathrm{ha}^{-1}$ & $279.4^{\mathrm{cd}}$ & $315.5^{\mathrm{cd}}$ & $299.4^{\mathrm{cd}}$ \\
$60 \mathrm{~kg} \mathrm{ha}^{-1}$ & $240.8^{\mathrm{d}}$ & $351.1^{\mathrm{bc}}$ & $443.5^{\mathrm{ab}}$ \\
$\mathrm{LCC}\left(60 \mathrm{~kg} \mathrm{ha}^{-1}\right)$ & $360.2^{\mathrm{bc}}$ & $300.1^{\mathrm{cd}}$ & $488.9^{\mathrm{a}}$
\end{tabular}

Treatment means in columns followed by common letters are not significantly different from each other based on DMRT at $5 \%$ level of significance.

Table 7. B: C ratio of black rice as influenced by the interaction between crop geometry and $\mathrm{N}$ management at Agronomy farm, AFU, Rampur in 2015-16.

\begin{tabular}{|c|c|c|c|}
\hline \multirow{3}{*}{ Nitrogen management practices } & \multicolumn{3}{|c|}{ B: C ratio } \\
\hline & \multicolumn{3}{|c|}{ Crop geometry } \\
\hline & $20 \mathrm{~cm} \times 20 \mathrm{~cm}$ & $20 \mathrm{~cm} \times 15 \mathrm{~cm}$ & $15 \mathrm{~cm} \times 15 \mathrm{~cm}$ \\
\hline $30 \mathrm{~kg} \mathrm{ha}^{-1}$ & $3.84^{\mathrm{cd}}$ & $3.90^{\mathrm{cd}}$ & $3.66^{\mathrm{cd}}$ \\
\hline $60 \mathrm{~kg} \mathrm{ha}^{-1}$ & $3.22^{d}$ & $4.40^{\mathrm{bcd}}$ & $5.27^{\mathrm{ab}}$ \\
\hline $\operatorname{LCC}\left(60 \mathrm{~kg} \mathrm{ha}^{-1}\right)$ & $4.74^{\mathrm{abc}}$ & $3.86^{\mathrm{cd}}$ & $5.76^{a}$ \\
\hline
\end{tabular}

Treatment means in columns followed by common letters are not significantly different from each other based on DMRT at $5 \%$ level of significance.

\section{Conclusion}

This investigation concluded that black rice is low responsive to applied nitrogen but found relatively higher uptake of nitrogen in LCC based nitrogen management in closer crop geometry (15 $\mathrm{cm} \times 15 \mathrm{~cm}$ ). Highest monetary return (404.0 thousand $\mathrm{ha}^{-1}$ ) and highest B: C ratio (5.76) can be obtained from LCC based nitrogen management with closer spacing $(15 \mathrm{~cm} \times 15 \mathrm{~cm})$. Therefore Black rice can be grown profitably in closer crop geometry (15 $\mathrm{cm} \times 15 \mathrm{~cm}$ ) with LCC based nitrogen management.

Open Access: This is an open access article distributed under the terms of the Creative Commons Attribution 4.0 License, which permits unrestricted use, distribution, and reproduction in any medium, provided the original author(s) if the sources are credited.

\section{REFERENCES}

Aulakh, M.S. and Singh, B. (1996). Nitrogen losses and fertilizer $\mathrm{N}$ use efficiency in irrigated porous soils. Nutrient Cycling in Agroecosystems, 47(3): 197-212, https://doi.org/10.1007/BF01986275

Bhat, T.A., Kotru, R., Verma, A., Ganai, M.A., Latie, Dar, L.A. and Teli, N.A. (2017). Leaf colour chart based $n$ management for yield, nutrient uptake and yield of rice genotypes. International Journal of Current Microbiology and Applied Sciences, 6(9): 3531-3538

Chaudhary, R.C. (2003). Speciality rices of the world: Effect of WTO and IPR on its production trend and marketing. Journal of Food, Agriculture and Environment, 1(2): 34-41

Dhyani, V.C., Chaturvedi, S. and Gouda, H.S. (2017). Growth, yield and nitrogen use efficiency in wheat as influenced by leaf color chart and chlorophyll meter based nitrogen management. International Journal of Current Microbiology and Applied Sciences, 6(12): 1696-1704.

Haque, M.A., Razzaque, A.H.M., Haque, A.N.A. and Ullah, M.A. (2012). Effect of plant spacing and nitrogen on yield of transplant aman rice var. BRRI dhan52. Journal of Bioscience and Agriculture Research, 4(02): 52-59.

Jena, S., Poonam, A. and Nayak, B.C. (2010). Response of hybrid rice to time of planting and plant density. ORYZA-An International Journal on Rice, 47(1): 48-52.

Karim, A.A. and C. Ramasamy. (2000). Expanding frontiers of agriculture: contemporary issues. Kalyani Publishers, Ludhiana, India.

Khadka, R.B. (2016). Evaluation of Black rice under different fertilizer doses in western Terai, Nepal. Nepal Journals Online, 4:136-141, http://dx.doi.org/10.3126/ ajn.v4i0.15536

Kumar, D., Devakumar, C., Kumar, R., Das, A., Panneerselvam, P. and Shivay, Y.S. (2010). Effect of neem-oil coated prilled urea with varying thickness of neem -oil coating and nitrogen rates on productivity and nitrogen-use efficiency of lowland irrigated rice under Indo-Gangetic plains. Journal of Plant Nutrition, 33(13):1939-1959, https://doi.org/10.1080/01904167.2010.512053

Kushwaha, U.K. (2016). Black rice anthocyanin content increases with increase in altitude of its plantation. Advances in Plants \& Agriculture Research, 5(1): 1-4, https://doi.org/10.15406/apar.2016.05.00170

Maiti, D., Das, D.K., Karak, T. and Banerjee, M. (2004). Management of nitrogen through the use of leaf color chart (LCC) and soil plant analysis development (SPAD) or chlorophyll meter in rice under irrigated ecosystem. The Scientific World Journal, 4: 838-846.

Mondal, M.M.A., Puteh, A.B., Ismail, M.R. and Rafii, M.Y. (2013). Optimizing plant spacing for modern rice varieties. International Journal of Agriculture \& Biology, 15(1): 175-178.

Peng, S., Cassman, K.G. and Kropff, M.J. (1955). Relationship between leaf photosynthesis and nitrogen content of field grown rice in the tropics. Crop Science, 35: 1627-1630.

Rakshit, A., Singh, H.B. and Sen, A. (2015). Nutrient use efficiency: From basics to advances. Springer, 417, https://doi.org/10.1007/978-81-322-2169-2 
Satpute, S.B., Surje, D.T. and Maity, S.K. (2014). Leaf colour chart based nitrogen management in rice-its economic, environmental and technological dimensions. Journal of Agriculture Technology, 1(2): 62-65
Sikdar, M.S.I., Rahman, M.M., Islam, M.S., Yeasmin, M.S. and Akhter, M.M. (2008). Effects of nitrogen level of aromatic rice varieties and soil fertility status. International Journal of Sustainable Crop Production, 3(3): 49-54. 